\title{
Effect of dangling chain content on properties of 10-undecenoic acid-based polyurethane
}

\author{
Bin Cui ${ }^{1,2}$, Changqing $\mathrm{Fu}^{1,2, a *}$ \\ (1.Department of polymer and coating, Jiangxi Science \& Technology Normal University, \\ Nanchang 330013, P.R.China; \\ 2. Jiangxi Engineering Laboratory of Waterborne Coating, Nanchang 330013, P.R.China) \\ a275341990@qq.com
}

Keywords: dangling chain; content; polyurethane

Abstract. A new linear 10-undecenoic acid-based diol and a chain extenders with 12C dangling chain length were synthesized via thiol-ene coupling and esterification reaction. In order to investigate the effect of the 10-undecenoic acid-based diol chain extender, the mole percent of the 10-undecenoic acid-based diol chain extender to the whole chain extender ranged from 0 to $100 \%(0 \%, 35 \%, 65 \%$, $100 \%)$. The thermal and crystal properties of 10-undecenoic acid-based polyurethanes were characterized by differential scanning calorimetry (DSC), thermogravimetric analysis (TGA) and (X-ray diffusion) XRD.The results show that with the increasment of dangling chain content, the glass transition temperature $\left(T_{g}\right)$ and melting temperature $\left(T_{m}\right)$ of polyurethane decreased obviously while the crystallinity decreased first and increased later.

\section{Introduction}

The polymer with dangling chain structure can be used as a plasticizer to reduce the hardness of the polymer and improve its flexibility ${ }^{[1]}$. There are a lot of researches about polyurethane containing the dangling chain have been reported ${ }^{[2-5]}$. Xu et al. ${ }^{[6]}$ fabricated segmented PUs with six-carbon dangling chain, they found that the presence of the six-carbon short dangling chain in each repeating unit of the soft segments does not limit the overall bulk properties. Yu et al. ${ }^{[2]}$ synthesized PUs with different dangling chain lengths and polar groups, their research results show that the Tg of the PU shifted to lower temperature with increasing dangling chain length. When the danling chain is introduced into the polymer, the arrangement regularity between molecules will be disturbed so as to reduce the intermolecular stacking. So the glass transition temperature and the melting temperature of the polyurethane can be reduced ${ }^{[7,8]}$. When the vegetable oil with $6-18 \mathrm{C}$ atoms chain react with the isocyanate, the introduction of dangling chain in the polyurethane will be realized. In the previous researches, the paper mainly introduces the influence of the dangling chain and the length of the dangling chain, and the research about the effect of the content of the danging chain is very little.

In this study, 10-undecenoic acid based polyol was prepared via esterification and Thiol-ene click reaction, and a chain extender with $12 \mathrm{C}$ dangling chain was prepared using methyl 10-undecenoate as raw material. By changing the mole fraction of 1,4-butanediol and the chain extender with 12C dangling chain, a series of PUs with different dangling chains content were prepared. The effect of the content of dangling chain on the thermal and crystalline properties of polyurethane was studied.

\section{Materials and methods}

10-undecenoic acid, methyl 10-Undecenoate, 2-mercaptoethanol, 3-mercapto-1,2-propanediol, Hexamethylene diisocyanate (HDI), p-toluenesulfonic acid (p-TSA), ditinbutyldilaurate (DBTDL) were obtained from Aladin China. N,N-dimethyl formamide (DMF) and dichloromethane (DCM) was obtained from Sinopharm Chemical, 2-hydroxy-2-methylpropiophenone (UV1173) was obtained from Jiuri Chemical of China.

Synthesis of polyol. According to the reference [9], 10-undecenoic acid (5.53g), p-toluensulphonic acid $(0.34 \mathrm{~g})$ and 1,4-butanediol (BDO) (1.35g) were dissolved in dichloromethane (8ml) in a 
single-necked flask. Then the mixture was stirred at $80^{\circ} \mathrm{C}$ for $8 \mathrm{~h}$. Then the mixture was cooled at room temperature overnight, the upper pale brown liquid was removed with a dropper. The product was produced by rotary evaporation. Then the produced product $(4.22 \mathrm{~g}), 2$-mercaptoethanol $(1.56 \mathrm{~g})$, and UV1173 $(0.08 \mathrm{~g})$ were dissolved in dichloromethane $(12 \mathrm{ml})$ in a single-necked flask. The reaction mixture was stirred at room temperature with UV light irradiation $\left(1700 \mu \mathrm{W} / \mathrm{cm}^{2}, 365 \mathrm{~nm}\right)$ for $6 \mathrm{~h}$. After confirming the completion of the reaction by the absence of the ${ }^{1} \mathrm{H}$ NMR shift of the $\mathrm{C}=\mathrm{C}$ group at 5.3 ppm to $5.7 \mathrm{ppm}$, then the 10-undecenoic acid based polyol was obtained by rotary evaporation to remove the solvent.

${ }^{1} \mathrm{H}$ NMR (400 MHz, $\left.\mathrm{CDCl}_{3}, \delta \mathrm{ppm}\right): 4.10\left(\mathrm{~d}, \mathrm{~J}=5.4 \mathrm{~Hz}, 4 \mathrm{H}, 2-\mathrm{O}-\mathrm{CH}_{2}\right), 3.72(\mathrm{dd}, \mathrm{J}=7.4,5.0 \mathrm{~Hz}, 4 \mathrm{H}$, $\left.2 \mathrm{HO}-\mathrm{CH}_{2}\right), 2.73\left(\mathrm{t}, \mathrm{J}=6.0 \mathrm{~Hz}, 4 \mathrm{H}, 2 \mathrm{~S}-\mathrm{CH}_{2}-\mathrm{CH}_{2}-\mathrm{OH}\right), 2.56-2.45\left(\mathrm{~m}, 4 \mathrm{H}, 2 \mathrm{~S}-\mathrm{CH}_{2}-\left(\mathrm{CH}_{2}\right)_{9}\right), 2.30(\mathrm{t}, \mathrm{J}=$ $\left.7.5 \mathrm{~Hz}, 4 \mathrm{H}, 2 \mathrm{CH}_{2}-\mathrm{C}=\mathrm{O}\right), 1.75-1.49\left(\mathrm{~m}, 12 \mathrm{H}, 6 \mathrm{CH}_{2}\right), 1.44-1.17\left(\mathrm{~m}, 24 \mathrm{H}, 12 \mathrm{CH}_{2}\right)$.

${ }^{13} \mathrm{C}$ NMR (101 MHz, $\left.\mathrm{CDCl}_{3} \delta \mathrm{ppm}\right): 173.65(\mathrm{~d}, \mathrm{C}=\mathrm{O}), 63.74\left(\mathrm{~s}, \mathrm{O}-\mathrm{CH}_{2}\right), 60.24\left(\mathrm{~s}, \mathrm{HO}-\mathrm{CH}_{2}\right), 35.20(\mathrm{~s}$, S- $\underline{\mathrm{CH}} 2-\mathrm{CH} 2-\mathrm{OH}), 34.30\left(\mathrm{~d}, \mathrm{C}=\mathrm{O}-\underline{\mathrm{CH}}_{2}\right), 32.30\left(\mathrm{~s}, \mathrm{~S}-\underline{\mathrm{C}} \mathrm{H}_{2}-\left(\mathrm{CH}_{2}\right)_{9}\right), 31.63\left(\mathrm{~s}, \mathrm{~S}-\mathrm{CH}_{2}-\underline{\mathrm{CH}}_{2}-(\mathrm{CH} 2)_{7}\right)$, $29.25\left(\mathrm{dd}, \mathrm{CH}_{2}\right), 25.13\left(\mathrm{~d}, \mathrm{CH}_{2}\right)$.

Synthesis of chain extender (DDC-12) According to the reference [9], methyl 10-Undecenoate $(0.99 \mathrm{~g}), 3$-mercapto-1,2-propanediol $(0.54 \mathrm{~g})$ and UV1173 $(0.02 \mathrm{~g})$ were dissolved in dichloromethane $(5 \mathrm{ml})$ in a singel-necked flask. The reaction mixture was stirred at room temperature with UV light irradiation $\left(1700 \mu \mathrm{W} / \mathrm{cm}^{2}, 365 \mathrm{~nm}\right)$ for $6 \mathrm{~h}$. After confirming the completion of the reaction by the absence of the ${ }^{1} \mathrm{H}$ NMR shift of the $\mathrm{C}=\mathrm{C}$ group at $5.3 \mathrm{ppm}$ to $5.7 \mathrm{ppm}$, the DDC-12 was obtained by rotary evaporation to remove the solvent.

$\left.{ }^{1} \mathrm{HNMR}\left(400 \mathrm{MHz}, \mathrm{CDCl}_{3}, \delta \mathrm{ppm}\right): 3.86-3.70\left(\mathrm{~m}, 2 \mathrm{H}, \mathrm{HO}-\mathrm{CH}_{2}-\mathrm{CH}(\mathrm{OH})\right)-\mathrm{CH}_{2}\right), 3.66\left(\mathrm{~s}, 3 \mathrm{H}, \mathrm{O}-\mathrm{CH}_{3}\right)$, $\left.\left.3.58-3.46\left(\mathrm{~m}, 1 \mathrm{H}, \mathrm{HO}-\mathrm{CH}_{2}-\mathrm{CH}(\mathrm{OH})\right)-\mathrm{CH}_{2}\right), 2.70\left(\mathrm{dd}, \mathrm{J}=13.7,4.5 \mathrm{~Hz}, 2 \mathrm{H}, \mathrm{HO}-\mathrm{CH}_{2}-\mathrm{CH}(\mathrm{OH})\right)-\mathrm{C}_{2}-\mathrm{S}\right)$, 2.62-2.57 (m, 2H, S-C $\left.\left.\underline{H}_{2}-(\mathrm{CH} 2)_{9}\right), 2.53\left(\mathrm{dd}, \mathrm{J}=14.3,7.0 \mathrm{~Hz}, 2 \mathrm{H}, \mathrm{HO}-\mathrm{CH}_{2}-\mathrm{CH}(\mathrm{OH})\right)-\mathrm{CH}_{2--} \mathrm{S}\right), 2.30$ $\left(\mathrm{t}, \mathrm{J}=7.6 \mathrm{~Hz}, 2 \mathrm{H}, \mathrm{CH}_{2}-\mathrm{C}=\mathrm{O}\right), 1.58\left(\mathrm{dt}, \mathrm{J}=21.3,7.2 \mathrm{~Hz}, 2 \mathrm{H}, \mathrm{CH}_{2}\right), 1.36(\mathrm{dd}, \mathrm{J}=16.3,9.6 \mathrm{~Hz}, 2 \mathrm{H}$, $\left.\mathrm{CH}_{2}\right), 1.27$ (s, $\left.12 \mathrm{H}, \mathrm{CH}_{2}\right)$.

${ }^{13} \mathrm{C}$ NMR (101 MHz, $\left.\left.\mathrm{CDCl}_{3}, \delta \mathrm{ppm}\right): 173.42(\mathrm{~s}, \mathrm{C}=\mathrm{O}), 69.29\left(\mathrm{~d}, \mathrm{HO}-\mathrm{CH}_{2}-\mathrm{CH}(\mathrm{OH})\right)-\mathrm{CH}_{2}\right), 63.96(\mathrm{~d}$ $\left.\left.\mathrm{HO}-\underline{\mathrm{CH}}_{2}-\mathrm{CH}(\mathrm{OH})\right)-\mathrm{CH}_{2}\right), \quad 50.17\left(\mathrm{~d}, \mathrm{O}-\mathrm{CH}_{3}\right), 34.21$ (d, $\left.\left.\mathrm{HO}-\mathrm{CH}_{2}-\mathrm{CH}(\mathrm{OH})\right)-\mathrm{CH}_{2}\right), 33.44-32.11(\mathrm{~m}$, S- $\left.\underline{\mathrm{CH}}_{2}-(\mathrm{CH} 2)_{8}-\underline{\mathrm{CH}}{ }_{2}\right), 31.29$ (d, S-CH$\left.{ }_{2}-\underline{\mathrm{CH}} 2-(\mathrm{CH} 2)_{8}\right), 29.06-26.30$ (m, $\left.\underline{\mathrm{CH}} 2\right), 23.66\left(\mathrm{~d}, \underline{\mathrm{CH}}_{2}\right)$.

Synthesis of polyurethanes and films. Polyurethanes were synthesized via a two-step polymerization process, where the molar ratio of polyol, diisocyanate and chain extender is 1:1.8:0.8. A dry 50ml round-bottom flask was charged with DMF, polyol, HDI and trace DBTDL. Subsequently, the mixture was heated to $80^{\circ} \mathrm{C}$ for $3 \mathrm{~h}$. Then the DDC- 12 chain extender was added and reacted for $3 \mathrm{~h}$. Finally BDO was added and reacted for $3 \mathrm{~h}$. Reaction completion was monitored by the absence of free-NCO-group IR absorption at $2270 \mathrm{~cm}^{-1}$. After confirming the completion of the reaction, the mixture was cooled at room temperature for a while. The mixture was then poured onto PTFE plates and placed in a oven at $100^{\circ} \mathrm{C}$ for $2 \mathrm{~h}$. Then the PTFE plates was taken out from the oven and remove them in the dryer inside. The detailed information of the obtained PUs was listed in Table 1.

Table 1 Designation of PU films

\begin{tabular}{lccccccc}
\hline Samples & Polyol(g) & HDI(g) & DDC-12 & BDO(g) & $\begin{array}{c}\text { DMF } \\
(\mathrm{g})\end{array}$ & $\begin{array}{c}\text { DBTDL } \\
(\mathrm{g})\end{array}$ & $\begin{array}{c}\text { Dangling } \\
\text { chain content }^{\mathrm{a}} \\
(\%)\end{array}$ \\
\hline PU1 & 0.58 & 0.27 & 0.00 & 0.05 & 6 & 0.05 & 0 \\
PU2 & 0.58 & 0.27 & 0.06 & 0.04 & 6 & 0.05 & 35 \\
PU3 & 0.58 & 0.27 & 0.12 & 0.02 & 6 & 0.05 & 65 \\
PU4 & 0.58 & 0.27 & 0.18 & 0.00 & 6 & 0.05 & 100 \\
\hline
\end{tabular}

a: indicates that diol with dangling chain posses percentage of the total molar amount of the chain extender. 


\section{Results and discussion}

FTIR study. The FTIR spectra of PUs are shown in Fig.1. The $\mathrm{N}=\mathrm{C}=\mathrm{O}$ stretching vibration band located at $2270 \mathrm{~cm}^{-1}$ is visibly missing, which confirms that all diisocyanate groups reacted during polymerization. The spectra exhibit absorption peaks at 3360 and $1530 \mathrm{~cm}^{-1}$, which are assigned to the stretching vibrations of $\mathrm{NH}$ and amide II in the urethane groups. $1730 \mathrm{~cm}^{-1}$ was ascribed to the free carbonyls vibration absorption in urethane. A stretching vibration band centered around $1680 \mathrm{~cm}^{-1}$, which is characteristic of the $\mathrm{H}$-bonded $\mathrm{C}=\mathrm{O}$ group in urethane ${ }^{[10]}$. From the above analysis, we successfully prepared polyurethane.

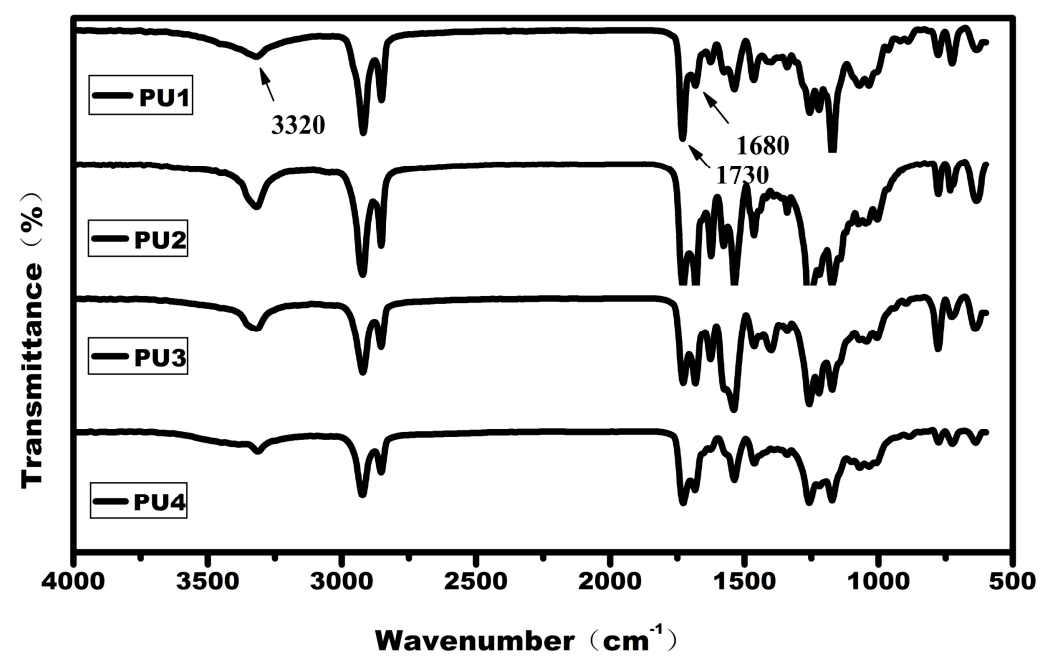

Fig.1 FTIR spectra of polyurethanes

Thermal behavior of the PUs. The glass transition temperature $\left(T_{g}\right)$ values and the melting temperature $\left(T_{m}\right)$ values of the PUs are summarized in Table 2. The PU1 without dangling chain has a higher $T_{\mathrm{g}}$ than others with dangling chain. The polyurethane with $100 \%$ dangling chain content has the lowest $T_{\mathrm{g}}$ and $T_{\mathrm{m}}$. The $T_{g}$ and $T_{\mathrm{m}}$ of PU1 and PU4 has obvious difference. We can see that the $T_{g}$ values and $T_{m}$ values both decrease when introducting dangling chain. This is because that the dangling chains increases the free volume and reduces the chain packing of the PUs ${ }^{[11]}$. So the dangling chain may function as a plasticizer, and it can decrease the $T_{g}$ and $T_{m}$.

The effect of dangling chain content on the thermal stability of the obtained PUs was investigated by TGA, as shown in Fig. 2 and Fig. 3. Their weight loss temperatures $\left(T_{\text {onset, }} T_{10 \%}, T_{50 \%} T_{\max }\right)$ are listed in Table 2. In comparison, the content of dangling chain has a little impact on the thermal stability of the obtained PUs. We can see from Fig.3, the polyurethane prepared all has 3 thermal decomposition stage, respectively for the decomposition of carbamate bond ${ }^{[2,13]}$, soft segment decomposition and decomposition of ester bond ${ }^{[7]}$.

Table 2 Thermal properties of PUs samples

\begin{tabular}{lllllll}
\hline Samples & $\mathrm{T}_{\mathrm{g}}\left({ }^{\circ} \mathrm{C}\right)$ & $\mathrm{T}_{\mathrm{m}}\left({ }^{\circ} \mathrm{C}\right)$ & $\mathrm{T}_{\text {onset }}\left({ }^{\circ} \mathrm{C}\right)$ & $\mathrm{T}_{10}\left({ }^{\circ} \mathrm{C}\right)$ & $\mathrm{T}_{50}\left({ }^{\circ} \mathrm{C}\right)$ & $\mathrm{T}_{\max }\left({ }^{\circ} \mathrm{C}\right)$ \\
\hline PU1 & 51.7 & 96.0 & 186.6 & 285.9 & 371.0 & 385.3 \\
PU2 & 43.5 & 90.4 & 196.4 & 270.9 & 368.9 & 381.1 \\
PU3 & 49.4 & 92.0 & 196.6 & 284.8 & 369.3 & 386.5 \\
PU4 & 36.6 & 84.8 & 195.6 & 267.1 & 371.1 & 377.1 \\
\hline
\end{tabular}




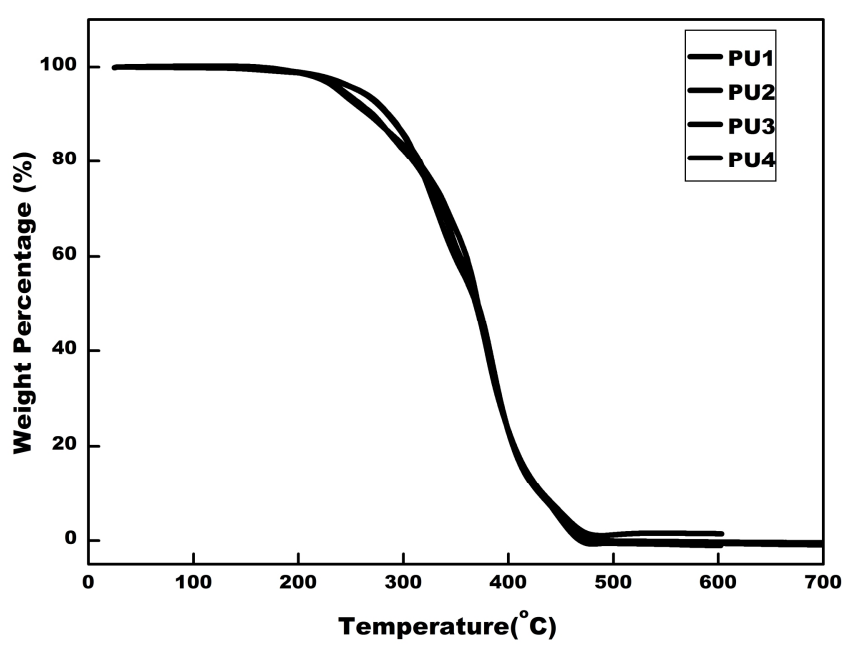

Fig. 2 TGA curves of the obtained PUs

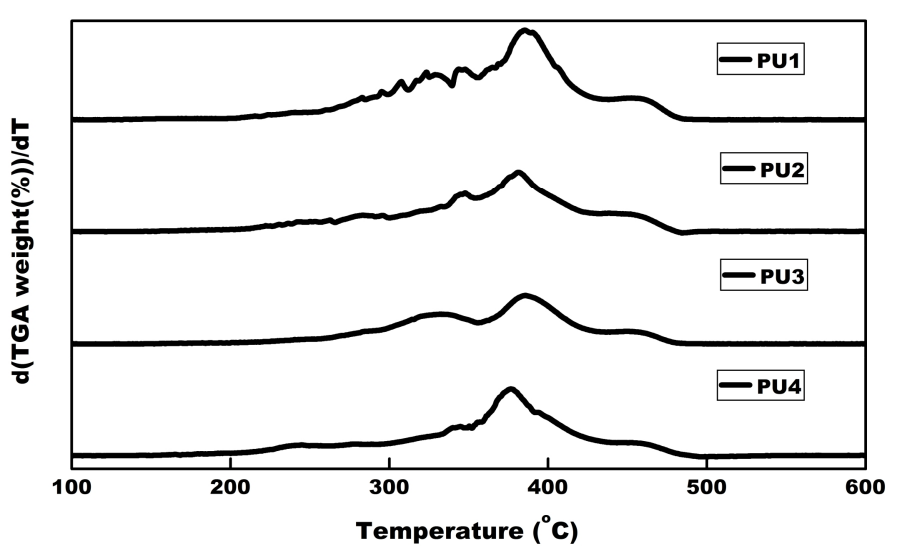

Fig. 3 TGA curves of the obtained PUs

X-Ray Diffraction of polyurethanes. The wide-angle X-ray diffraction pattern of PUs are shown in Fig.4. The wide diffraction peak in the range of 10 degree to 25 degree indicates that the PUs is amorphous. PU1 appears as a sharp diffraction peak at 13 degree, which is the diffraction peak of the crystal structure. It can also be seen from Fig. 4, in addition to PU1, PU2 and PU3 in the vicinity of $13^{\circ}$ almost has no diffraction peak, which showed the presence of the dangling chain disrupts the orderly and hinders the crystallization of hard segments ${ }^{[14]}$. In addition, there was a bigger shaper diffraction peaks at around $14^{\circ}$ in PU4, in which the dangling chains content reached $100 \%$. The reason may lie in the H-bond in hard segments is strengthened when polar groups are introduced to the dangling chain, leading to enhancement of the microphase separation, so the crystallinity becomes stronger when the dangling chains content reached $100 \%$.

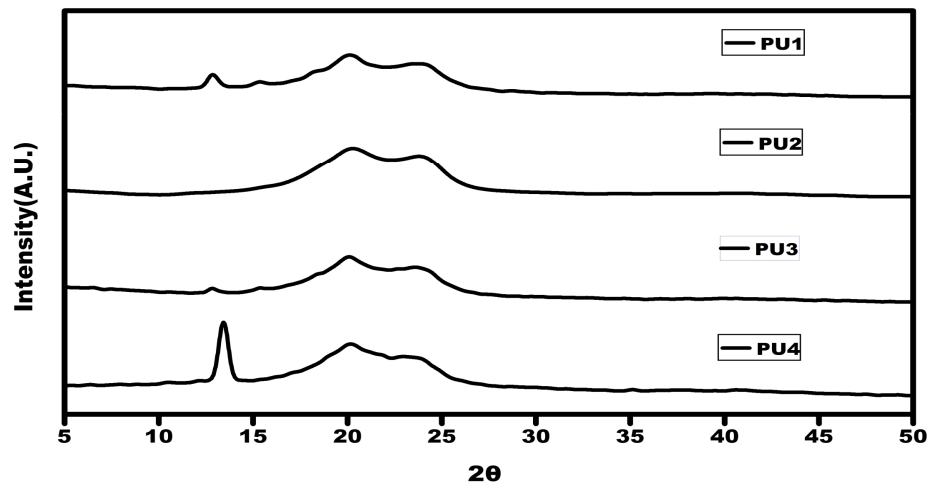

Fig. 4 X-Ray Diffraction of PU films 


\section{Conclusions}

In this paper, a polyol and a diol chain extender with $12 \mathrm{C}$ dangling chain length were successfully prepared. And a series of polyurethane with dangling chain content of $100 \%, 65 \%, 35 \%$ and $0 \%$ were prepared. In the prepared polyurethanes, the thermal properties of the polyurethanes with $0 \%$ and $100 \%$ dangling chain content had obvious difference. X-ray diffraction results showed that the crystallinity of polyurethane with a certain degree of dangling chain content was lower than that of the polyurethane with no danging chain.

\section{Acknowledgements}

This work was financially supported by National Natural Science Foundation of China (51263011), Jiangxi Province Natural Science Foundation of China (20142BAB203016) and Jiangxi Science and Technology Normal University university innovation team(2013).

\section{References}

[1] A.S. More, S.K. Pasale and P.P. Wadgaonkar: European Polymer Journal Vol. 46 (2011), p. 557.

[2] W. Yu, M. Du, D. Zhang, Y. Lin and Q. Zheng: Macromolecules Vol. 46 (2013), p. 7341.

[3] Y.W. Song , Z.G. Jiang, H.Q. Wang and X.Y. Li: New Chemical Materials Vol. 36 (2008), p. 42.

[4] P.D. Pham, V. Lapinte, Y. Raoul and J.J. Robin: Journal of Polymer Science Part A: Polymer Chemistry Vol. 52 (2014), p. 1597.

[5] A.S. More, L. Maisonneuve, T. Lebarbé, B. Gadenne, C. Alfos and H. Cramail: European Journal of Lipid Science and Technology Vol. 115 (2013), p. 61.

[6] Y. Xu, Z. Petrovic, S. Das and G.L. Wilkes: Polymer Vol. 49 (2008), p. 4248.

[7] T.S. Velayutham, W.H. Abd Majid, A.B. Ahmad, Y.K. Gan and S.N. Gan: Journal of Applied Polymer Science Vol. 112 (2009), p. 3554.

[8] D.H. Wang, Z. Shen, M. Guo, S.Z. Cheng and F.W. Harris: Macromolecules Vol. 40 (2007), p. 889.

[9] C.Q. Fu, B. Cui and L. Shen: Polymer Materials Science \& Engineering Vol. 31 (2015), p. 1.

[10] H.S. Lee, Y.K. Wang and S.L. Hsu: Macromolecules Vol. 20 (1987), p. 2089.

[11] C. Bueno-Ferrer, E. Hablot, F. Perrin-Sarazin, M.C. Garrigós, A. Jiménez and L. Averous: Macromolecular Materials and Engineering Vol. 297 (2012), p. 777.

[12] M. Kashif, E. Sharmin, F. Zafar and S. Ahmad: Journal of the American Oil Chemists' Society Vol. 88 (2011), p. 1989.

[13] G. Lligadas, J.C. Ronda, M. Galia and V. Cádiz: Biomacromolecules Vol. 8 (2007), p. 686.

[14] A.S. More, S.K. Pasale and P.P. Wadgaonkar: European Polymer Journal Vol. 46 (2010), p. 557. 